(C) 2005 The Modern Schoolman 83(1): 65-77.

\title{
Pomponazzi and Aquinas on the Intellective Soul
}

\author{
Jason T. Eberl
}

$\underline{\text { Introduction }}$

One of Thomas Aquinas's primary philosophical concerns is to provide an account of the nature of a human soul. He bases his account on Aristotle's De anima $[D A]$, wherein Aristotle gives an account of "soul" (psuchē) as divided into three distinct types: vegetative, sensitive, and intellective. Aristotle defines an intellective soul as proper to human beings and the only type of soul that may potentially exist separated from a material body. ${ }^{1}$ Aquinas argues that an intellective soul is indeed separable from its body and conceives of it as essentially, or unqualifiedly (simpliciter), immortal and separable from its body, and relatively (secundum quid) mortal and conjoined to its body. Pietro Pomponazzi (1462-1525), a Renaissance philosopher concerned with ridding neoAristotelianism of Platonic or Averroistic influences, criticizes Aquinas's account as not being properly Aristotelian and having been influenced by Platonism. ${ }^{2}$ In this paper, I will present summaries of Aquinas's arguments concerning an intellective soul's essential immortality, as well as Pomponazzi's criticisms of Aquinas's position. I then propose ways in which Aquinas may respond to these criticisms.

\section{Aquinas's Arguments for an Intellective Soul's Immortality ${ }^{3}$}

Aquinas follows Aristotle in holding that an intellective soul is the substantial form of a human being. As a substantial form, an intellective soul is responsible for (1) a human being's existence (esse), (2) the actualization of the matter that constitutes a human being, and (3) the unity of existence and activity in a human being. ${ }^{4}$ Aquinas 
further argues that an intellective soul has a mode of being that distinguishes it from all other substantial forms of material substances. ${ }^{5}$ This distinction is due to intellective functioning not being dependent upon any material organ. Aquinas, again following Aristotle, holds that intellective activity surpasses the limits of matter in its understanding the universal, intelligible forms of things; such universal forms are the natures of things understood as abstracted from any particular material conditions - e.g., understanding the concept "humanity" instead of just this human being. Since intellective activity surpasses the limits of individuated matter, no purely material process can be responsible for the generation of substantial forms with the capacity for such activity. All other substantial forms of material substances can be generated through purely material processes. Aquinas thus argues that an intellective soul has its esse directly from God, ${ }^{6}$ and is something both incorporeal and subsistent on its own. ${ }^{7}$

That an intellective soul is subsistent and incorporeal, Aquinas argues, implies its incorruptibility, i.e., its immortality. Aquinas notes that something can be corruptible in two ways: per se - through itself — and per accidens - through another. No substantial form is corruptible per se, because corruption per se involves the separation of a thing from its substantial form. A substantial form cannot separate from itself. Hence, since an intellective soul is a substantial form, it is not corruptible per se. Substantial forms of material things, however, such as a rock, are corruptible per accidens. Material substantial forms are corruptible per accidens, because they are completely dependent for their subsistence and operation upon the bodies they inform. When such bodies are corrupted, their substantial forms are corrupted as well. An intellective soul is an exception. Though it is the substantial form of a material body, an intellective soul has 
its esse directly from God and also has an operation, viz., intellective cognition, which does not depend upon any bodily organ for its functioning. Therefore, an intellective soul cannot be corrupted either per se, as is the case with any substantial form, or per accidens, due to its lack of complete dependence upon a material body for its subsistence and operation. ${ }^{8}$

Some capacities of an intellective soul, viz., its vegetative and sensitive capacities, do act through bodily organs. Thus, it is not the case that an intellective soul is completely independent of its body; for some of its functions must be exercised through bodily organs. Hence, an intellective soul's separable existence does not entail that all of its capacities can be actualized in such a state. An intellective soul requires a material body to function completely, i.e., for all of its capacities to be actualizable. Furthermore, Aquinas argues that an intellective soul communicates its esse to a material body such that there is one esse of a composite substance: a human being. As a result, an intellective soul must be immediately conjoined to its body. ${ }^{9}$ Additionally, while intellective activity does not itself require a bodily organ, ${ }^{10}$ an intellect operates by abstracting universal forms from "phantasms" (phantasmata). ${ }^{11}$ An intellect has such phantasms through sense-perception of particular material substances. ${ }^{12}$ Since the activity of sense-perception requires proper bodily organs - eyes, ears, nose, brain, etc.an intellect does have need of a material body, at least initially. ${ }^{13}$ It thus appears that, while Aquinas does not himself use these terms, Pomponazzi is correct in ascribing to Aquinas the position that an intellective soul is essentially (simpliciter) immortal, due to its distinctive intellective function not requiring a bodily organ to operate, and relatively (secundum quid) mortal in that it naturally exists conjoined to a corruptible material body 
for the sake of its vegetative and sensitive operations, as well as for the intellect to be provided with phantasms from which it may abstract intelligible forms.

\section{Pomponazzi's Critique of Aquinas's Position}

In his Tractatus de immortalitate animae (1516), ${ }^{14}$ Pomponazzi puts forth two criteria by which previous arguments for an intellective soul's immortality, viz., those of Averroes and Aquinas, ought to be judged. The first criterion is that propositions concerning an intellective soul's immortality ought to be formed "leaving aside revelation and miracle, and remaining entirely within natural limits." ${ }^{\prime 15}$ The second criterion requires the propositions asserted to be properly "Aristotelian."16 Pomponazzi then proceeds to demonstrate how Aquinas's account of an intellective soul's immortality fails to meet these criteria. ${ }^{17}$

First, Aquinas's argument for an intellective soul being properly immortal and relatively mortal can be used to prove the opposite to be the case. Pomponazzi contends that, just as an intellective soul's operation of receiving all material forms, not using a bodily organ, and aspiring to eternal things ${ }^{18}$ may be employed in an attempt to demonstrate its immortality, its not being able to receive all material forms in its vegetative part, its use of bodily organs in sensation, and its pursuit of temporal things may be used to demonstrate its mortality. Pomponazzi's contention, though, shows merely that there are two possible conclusions regarding an intellective soul's nature: either it is essentially immortal and relatively mortal, as Aquinas argues, or vice versa, as Pomponazzi argues, and "the argument for one conclusion seems to be no stronger than for the other."19 
In his second criticism, Pomponazzi supports the latter conclusion through an additional argument that, since an intellective soul tends, in its capacities, more towards the mortal than the immortal, it is more properly considered as mortal: "[Human] existence is more sensuous than intellective, more mortal than immortal." ${ }^{, 20}$ Among the reasons Pomponazzi provides for this conclusion is the following:

For if we consider the number of powers in man, we find only two which attest to immortality, the intellect and the will; but innumerable powers of the sensitive and vegetative soul, which all attest to mortality. ${ }^{21}$

Pomponazzi's third criticism is that it is not immediately known that an intellective soul is immortal, and there is no evidence of such immortality that is not contradicted by some necessary condition of an intellective soul. For example, the necessity of imagination for understanding, by providing phantasms for intellectual abstraction, contradicts the idea that an intellective soul can come to know things in a separated state. Pomponazzi notes that Aristotle says something similar by first asserting a conditional, "If [intellective understanding] too is a kind of imagination, or at least is dependent upon imagination, even this cannot exist apart from the body,"22 and later affirming the antecedent, "the soul never thinks without a mental image (phantasmatos)., ${ }^{, 23}$

Pomponazzi's fourth criticism asserts the conclusion drawn from the above consideration: "If the human soul is dependent in all its operations on some organ, it is inseparable and material; but in all its operations it is dependent on some organ; hence it is material." 24 Pomponazzi reinforces an intellective soul's essential mortality by reference to Aristotle's definition of it, adopted by Aquinas, "as the first actuality of a 
natural body potentially possessing life." ${ }^{, 25}$ I will consider this criticism in more detail in the next section.

Pomponazzi's fifth criticism of Aquinas's position is that, if an intellective soul is truly sensitive and vegetative, then after separation from its body it either has the power to perform its sensitive and vegetative functions or it does not. Pomponazzi states that if the former were true, then those capacities would be in vain since a separated soul has the use of no organs, which are necessary for the actualization of vegetative and sensitive capacities. But, if the latter were true, then the soul would be deprived of its natural capacities for all eternity, which Pomponazzi considers to be absurd. In his final criticism, Pomponazzi states that Aristotle himself concludes ${ }^{26}$ that an intellective soul is essentially corruptible and relatively incorruptible. ${ }^{27}$

Thomistic Response to Pomponazzi

Having outlined Pomponazzi's six criticisms of Aquinas's position that an intellective soul is essentially immortal and relatively mortal, I turn now to address each criticism from the perspective of Aquinas's overall account of human nature. I intend to respond to Pomponazzi's criticisms in a Thomistic fashion in order to preserve both the rational foundation of Aquinas's account and its properly Aristotelian character.

As noted above, Pomponazzi's second criticism is supportive of his first in concluding that human nature is "more sensuous than intellective" and thus "more mortal than immortal" against Aquinas's contention that an intellective soul is essentially immortal. Both criticisms can thus be overcome if it can be shown that human nature does not tend more towards the sensitive and mortal than the intellective and immortal. Such a demonstration can be made given Aquinas's hierarchical account of reality and 
the capacities reflective of the various types of soul that inform various grades of 1 ife. ${ }^{28}$ Following Aristotle, ${ }^{29}$ Aquinas contends that an intellective soul is the "highest" type of soul and contains within its set of capacities those that belong to the "lower" types of soul, viz., the sensitive and vegetative. In comparing intellective capacities to sensitive capacities, Aquinas asserts, "the intellective powers are prior to the sensitive powers; whence they direct them and command them."30 Therefore, in a human being, the intellect is "more perfect" and has the ability to control certain capacities proper to the lower types of soul. It is due to this hierarchy that one may conclude, in an Aristotelian fashion, that a sensitive animal is a higher form of life than a merely vegetative plant, and an intellective human being is a higher form of animal life than a dog or a horse. The intellective capacity is qualitatively more significant than the more numerous sensitive and vegetative capacities had by a human being informed by an intellective soul.

I will next discuss Pomponazzi's fifth and sixth criticisms and then return to consider his third and fourth. In his fifth criticism, Pomponazzi proposes a dilemma regarding the presence of vegetative and sensitive capacities in a separated intellective soul: either a separated intellective soul has such capacities in vain, because it lacks bodily organs through which it can exercise them, or it does not have such capacities and is thus deprived of its natural condition for all eternity. Aquinas considers it important that an intellective soul maintain the vegetative and sensitive capacities that are proper to it. Aquinas must admit, though, that a separated intellective soul cannot exercise such capacities insofar as they depend on bodily organs to operate. This does not, however, imply that a separated intellective soul has such capacities "in vain." Aquinas argues that it is naturally necessary that a separated intellective soul re-inform its body at some point. 
Re-informing its body allows an intellective soul to exercise once again its vegetative and sensitive capacities. Aquinas holds that an intellective soul cannot remain perpetually in a separated state, since such a state is unnatural for it:

It must be that a state in which the soul is separated from the body is per accidens and contrary to nature, if the soul naturally and per se longs to be united to the body. Hence, the soul will not be separated from the body forever. Therefore, since its substance is incorruptible ... it is left open for it to be reunited to the body. $^{31}$

The souls of human beings are immortal ... [but] the soul is naturally united to the body, for it is essentially the form of the body. It is thus contrary to nature for the soul to be without the body. But nothing which is contrary to nature can exist forever. Therefore, the soul will not be without the body forever ... Hence, the soul's immortality appears to require the body's future resurrection. ${ }^{32}$

Aquinas concludes that an intellective soul will be rejoined to the body it previously informed at some point after death. The vegetative and sensitive capacities it possesses during its separated state thus do not exist in vain.

Pomponazzi's sixth criticism is the charge that Aquinas's position is not properly Aristotelian. Pomponazzi claims that Aristotle explicitly states in $D A$ that an intellective soul is essentially mortal and relatively immortal, in that only one part of it $-v i z$., the "active" intellect — is "separable, impassive and unmixed [with a body]."33 Unfortunately, it is not at all clear precisely what Aristotle intends to assert in the passage to which Pomponazzi refers. ${ }^{34}$ In fact, the difference between the Averroistic and Thomistic understandings of Aristotle's account centers on the interpretation of this 
passage. The Latin Averroists took the passage to imply that there is a single active intellect, which is essentially immortal, and actualizes the "possible" intellect present in each human soul. Based on this understanding, the Latin Averroists held that the intellective soul of individual human beings perishes when the body it informs is corrupted; only the universal active intellect persists beyond the death of individual human beings. Aquinas's interpretation is that there is one intellect present in each human being's soul and this intellect can be understood in two ways: insofar as it is active and thus able to abstract intelligible forms from phantasms, and insofar as it is passive and thus able to receive the abstracted intelligible forms. ${ }^{35}$ It would require adjudication of this dispute to determine this passage's usefulness in supporting Pomponazzi's claim that Aquinas's account is not properly Aristotelian, and such adjudication is outside the scope of this paper. Suffice it to say that Pomponazzi's case is quite weak if this contentious passage is the only textual evidence he has to support his interpretation of Aristotle.

I will now consider Pomponazzi's third and fourth criticisms, which I take as his most powerful objections to Aquinas's position. In his third criticism, Pomponazzi raises the issue of an intellect's dependence upon phantasms derived from sensation for its abstraction of intelligible forms. Due to this dependence relationship, clearly acknowledged by Aristotle and Aquinas, ${ }^{36}$ Pomponazzi concludes in his fourth criticism that an intellective soul is not essentially immortal, because it is (1) dependent upon bodily organs for sensation and the production of phantasms, and (2) essentially the substantial form of a body according to its definition as a "soul." 
Pomponazzi considers the objection that an intellective soul, with respect to its intellective function, is not the form of an organic body since intellective activity is not the form of any body. Pomponazzi rejects this contention on the basis that, if such were the case, an intellective soul would not be a soul, since it would not be the form of a material body. This would contradict Aristotle's definition of "soul." He also asserts that as long as one maintains intellective understanding to be a function of a soul, and a soul, by definition, is the form of a body, then there must be a body for it to inform.

In response to these points, it may be argued that it is not necessary for an intellective soul always to depend on a bodily organ, although it depends initially on one. Its apparent dependence is merely an aptitude. Pomponazzi contends that this response is deficient, however. First, if aptitude alone were enough to satisfy a definition, it would follow that something could be called a human being and yet not be a "rational animal," but merely have an aptitude for rationality. ${ }^{37}$ I respond that an aptitude for rationality is sufficient to satisfy definition of a human being. A newborn child, or a severely mentally disabled person, does not actually function as a rational animal. They operate mainly on instinct and in many ways are no more intellectually developed than a brute animal, except for the fact that, unlike brutes, children and the severely mentally disabled have an inherent aptitude for rationality. They have not actualized this aptitude due to either a lack of development which will come in time (as in the case of children) or an impediment which limits the level of development that may be reached (as in the case of the severely mentally disabled). Therefore, since both children and severely mentally disabled persons are considered human beings, despite a lack of actual rational functioning, an aptitude for rationality must be sufficient to satisfy the definition of a 
human being. ${ }^{38}$ Pomponazzi's analogy is thus improper and does not support his contention.

Pomponazzi's second complaint is that an intellective soul's dependence on imagination for phantasms, even if it is only an aptitude, makes it inseparable and essentially mortal. What I willingly grant is that a natural aptitude for utilizing a function of a body implies a natural aptitude for being conjoined to that body in order to utilize its functions. But Pomponazzi's argument requires a stronger premise, one that I do not grant: that an intellect's aptitude for utilizing imagination implies a necessary connection to a body and the intellect's material existence. The term "aptitude" refers to a property that may be natural, i.e., included in the design of how a subject is to interact with other things in the world, but is not necessarily an essential property of the subject as it is in itself. This is what Aquinas argues is the case for an intellective soul. An intellective soul is essentially immaterial and incorruptible. It is, however, naturally conjoined to a body for the sake of actualizing all of its capacities by utilizing bodily organs. Pomponazzi's contention depends on the property of having a natural aptitude to use bodily organs, and thereby being conjoined to a body, implying a necessary relationship to a body. It is far from clear, however, that such an implication is valid.

Aquinas recognizes that an intellective soul's natural aptitude for understanding by means of abstraction from phantasms may imply that a separated intellective soul cannot function, which would in turn, following Aristotle, imply its inseparability and essential mortality. Nevertheless, he responds:

Now the soul has one mode of being when it is united to the body, and another when it is separated from the body, yet the soul's nature remains the same. It 
does not follow that its union with the body is accidental, but by reason of its nature it is united to the body ... Therefore, the soul, according to its mode of being when it is united to the body, has a mode of understanding by turning to corporeal phantasms, which are in corporeal organs; but when it is separated from the body, it has a mode of understanding by turning to what is simply intelligible, just as other separated substances. Hence, the mode of understanding by turning to phantasms is as natural to the soul as its being united to the body; but to be separated from the body is not in accordance with its nature, and similarly to understand without turning to phantasms is outside its nature. And thus it is united to the body so that it may exist and operate according to its nature ... It is thus clear that it is for the sake of the soul's good that it is united to the body, and understands by turning to phantasms; and nevertheless it can exist separated, and have another mode of understanding. ${ }^{39}$

Aquinas thus concludes that an intellective soul, while it has a natural aptitude for understanding by means of sensation and abstraction from phantasms, can also understand by another means: direct access to intelligible forms. ${ }^{40}$ This mode of understanding goes against its natural aptitude, but yet allows for an intellective soul to function without a body and thus be essentially immortal. ${ }^{41}$ Furthermore, Aquinas asserts that an intellective soul, once separated from its body, retains the intellectual memory of the intelligible forms it had abstracted from phantasms produced from sense-perception while embodied. As a result, a separated intellective soul can engage in "the act of knowledge," which consists of reflection upon the intelligible forms it has already received: 
Therefore, since intelligible species remain in the separated soul, as has been stated ${ }^{42}$ and since the state of the separated soul is not the same as it is presently [in this life], it follows that through the intelligible species acquired here [in this life], the separated soul can understand what it understood prior, but not in the same mode, namely by conversion to phantasms, but by a mode suited to a separated soul. And thus the act of knowledge acquired here [in this life] indeed remains in the separated soul, but not in the same mode. ${ }^{43}$

To understand this claim, and how it is consistent with Aquinas's contentions that an intellect can function on its own without any need of a bodily organ and yet requires phantasms received through sensation in order to function naturally, consider the following analogy. A computer's central processing unit (CPU) has, in itself, the ability to process and analyze data, as well as to store and recall it through its RAM and ROM capacities. ${ }^{44}$ It is thus independent in its function and thereby separable from the monitor, keyboard, mouse, hard drive, and all other hardware components that constitute the whole computer. The CPU's RAM and ROM, however, must have data written to them for the CPU to process and analyze. Hence, data input mechanisms such as the keyboard, mouse, etc. are required to provide the data for the CPU to store, recall, process, and analyze. So, while the CPU's definitive function of analyzing and processing data, as well as storing and recalling such data, does not require any other hardware components, it cannot actually perform this function without having had data provided through its input devices. Once provided, though, those devices may cease to exist without depriving the $\mathrm{CPU}$ of its functioning. Thus, a computer as a whole functions naturally and optimally when the CPU and other data input devices are present, 
connected, and functioning together. If, however, a computer's CPU could have the data it needs to function provided to it in some other fashion, then it could function completely on its own without the computer's other hardware components. Analogously, an informed human body, with its sense organs and brain that provide the faculties of sensation and imagination to produce phantasms, is naturally suited to provide such phantasms for its soul's intellect to function. Nevertheless, with the possibility of direct access to intelligible forms and retention of the intelligible forms already received through previous acts of sense-perception, a separated intellective soul can function on its own, albeit unnaturally and imperfectly, without need of phantasms.

Pomponazzi further challenges Aquinas's claim of an intellective soul's separability by arguing that its definition as the substantial form of an organic body implies its essential union with such a body. Pomponazzi thus raises the question: How can something be "the substantial form of X" without there being an X? In other words, if it is definitive of an intellective soul that it be the substantial form of a body, then it would seem that there must always be a body which it informs. Aquinas agrees that an intellective soul is, by definition, the form of a body. Since, however, Aquinas holds that an intellective soul is separable from its body, there will be a period of time after separation when it is not actually the form of a body. ${ }^{45}$ According to Pomponazzi, this state of affairs is so problematic that an intellective soul should not be considered as properly immortal.

A means of responding to this issue begins with a consideration of an intellective soul's two states of existence — conjoined to a body and separated—in conjunction with the notion that an intellective soul's essential properties need not always be full, or what 
is often termed by Aristotelian scholars "second," actualizations. ${ }^{46}$ As discussed above, a mere "potential actualization," or aptitude, is enough to satisfy the definitional requirement of something being an actuality. ${ }^{47}$

Aristotle holds that an intellective soul is an actuality and is not actualized by anything outside of itself. ${ }^{48}$ This is not to say that an intellective soul actualizes itself, but since its essential nature is as an actuality, it must be actualized at the moment it comes into being. Now, since an intellective soul is immediately conjoined to a body and is an actuality by nature, it actualizes its body and also actually thinks while it is conjoined to its body. But there is a question whether both of these characteristics of an intellective soul must be actualized for the soul itself to be considered as an actuality. In other words, if an intellective soul actually thinks, it is an actuality, and if it is actually the form of a body, it is an actuality. It seems that only one of these actualizations need occur if an intellective soul is to be an actuality.

When an intellective soul is conjoined to a body, it both actualizes the body and actually thinks. What happens when the body is corrupted and the intellective soul separates but continues to exist? It ceases to be the actual form of a body, for there is no longer a body. But this does not violate the intellective soul's essential nature as the form of a body, for it maintains the potentiality to be the form of that particular body. On Aquinas's understanding of the Christian doctrine of bodily resurrection, a separated intellective soul re-actualizes the particular body of which it is the form and first actuality. ${ }^{49}$ The soul re-actualizes the same body, because it maintains in potentia, in its separated state, the "blueprint" for that particular body which it had previously informed. Because a separated intellective soul maintains, at least potentially, the essential property 
of being the first actuality of a particular body, Aristotle's definitional requirement is satisfied. Additionally, an intellective soul maintains its essential nature as an actuality in its separated state, because it actually thinks in such a state. ${ }^{50}$ Therefore, an intellective soul both remains an actuality after separation from its body and has a potential, or "first," actualization to be the substantial form of the same body at Resurrection.

To summarize the preceding argument, I first claim that on Aristotle's account there are two ways for an intellective soul to be considered an "actuality": (1) as a thinking thing and (2) as the actualization of a body. I further claim that an intellective soul, both while conjoined to a human body and when separated from it by death, can always be characterized in terms of at least one of the above actualities. When conjoined to its body, an intellective soul is both actualizing the body and is actually thinking. When separated from its body, an intellective soul still actually thinks; and, surely, as Descartes has shown, to think is to actually be. Finally, I claim that, even at times when an intellective soul cannot actually be characterized in terms of one of the above actualities, i.e., it is does not possess one of them as a second actualization, it still possess it as a first actualization and such is sufficient to satisfy any definitional requirement. Therefore, when an intellective soul is not conjoined to its body, it maintains its essential nature as something that actually thinks with the potential to be the actuality of a particular body.

Conclusion

I conclude that Pomponazzi does not effectively demonstrate that Aquinas's account of an intellective soul being essentially immortal and relatively mortal is either not founded on reason alone or not properly Aristotelian. While some of the Thomistic 
responses to Pomponazzi I have provided involve the assertion of bodily resurrection, Aquinas considers bodily resurrection and the reunion of an intellective soul with its body to be metaphysically mandated and not just an event that is provided by divine fiat. ${ }^{51}$ That a separated intellective soul maintains its essential nature as both an actually thinking entity and the substantial form of a particular body allows Aquinas to conclude that an intellective soul is essentially immortal, due to its intellective capacities that do not necessarily require a bodily organ to operate, and relatively mortal, due to its natural relationship to a material human body. Since it is arguable that Aristotle advocates an intellect's separable functioning, as well as its being the form of a material body, permits Aquinas's account to be considered as a valid interpretation of Aristotle's De anima. ${ }^{52}$

\footnotetext{
${ }^{1}$ The terms "human soul" and "intellective soul" will be used interchangeably.

${ }^{2}$ For Pomponazzi's intellectual development, from his early adherence to Thomism through his later rejection of it, see Paul Oskar Kristeller, Renaissance Thought and Its
} Sources (New York: Columbia University Press, 1979), chs. 9-10. For essays regarding the interpretation of Aristotle's philosophy and his commentators in Pomponazzi's time, see Constance Blackwell and Sachiko Kusukawa, eds., Philosophy in the Sixteenth and Seventeenth Centurties: Conversations with Aristotle (Brookfield: Ashgate, 1999).

${ }^{3}$ This section is drawn from my "Aquinas on the Nature of Human Beings" Review of Metaphysics 58/2 (2004): pp. 333-65.

${ }^{4}$ See Aquinas, Summa contra Gentiles [SG]: II.68; Aquinas, In Aristotelis librum De anima commentarium: II.2.

${ }^{5}$ See Aquinas, Scriptum super sententiis magistri Petri Lombardi [CS]: I.8.v.2.ad 1. 
${ }^{6}$ See Aquinas, In librum de causis expositio [CLC]: V; Aquinas, Summa theologiae [ST]:

I.90.2, 118.2.

${ }^{7}$ See $S T:$ I.75.1-2, 5 .

${ }^{8}$ See Aquinas, Quaestiones disputatae de veritate [DV]: XIII.4; ST: I.75.6. Also, in CLC: $\mathrm{XV}$, Aquinas argues that an intellective soul's ability to "turn back on itself," i.e., to reflexively know itself, requires that it be separable from its body.

${ }^{9}$ See Aquinas, Quaestiones disputatae de anima [QDA]: I.ad 1; Kevin White, “Aquinas on the Immediacy of the Union of Soul and Body" in Paul Lockey, ed., Studies in Thomistic Theology (Houston: Center for Thomistic Studies, 1995), pp. 209-80.

${ }^{10}$ Aquinas would thus disagree with the material reductionist position popular among philosophers of mind. An intellect is not identical with, or reducible to, a human brain; although Aquinas admits some relationship between a brain and certain "cogitative" operations of an intellective soul. See $D V$ : X.5; ST: I.78.4; Eleonore Stump, "NonCartesian Substance Dualism and Materialism Without Reductionism," Faith and Philosophy 12 (1995): pp. 505-31; Eberl, op. cit. note 3.

${ }^{11}$ See $S T$ : I.84.7, 85.1. The term "phantasmata," transliterated as "phantasms," is sometimes translated as "sense-impressions" or "sensory images." Such translations, however, are problematic. As Robert Pasnau describes it, "phantasms are not simply our ordinary sensory images. Rather, phantasms are the leftover impressions from those sensory images" (Robert Pasnau, Thomas Aquinas on Human Nature (New York: Cambridge University Press, 2002), p. 279; see pp. 278-95). Norman Kretzmann describes them as "cognitive likenesses of particular external things reinstated in physical configurations of the organ of phantasia [i.e., the brain]" (Norman Kretzmann, The 
Metaphysics of Creation: Aquinas's Natural Theology in Summa Contra Gentiles II (New York: Oxford University Press, 1999), p. 355; see pp. 350-64). The purpose of phantasms is to be available for the intellect to use in abstracting the intelligible forms of perceived things. Hence, phantasms are between the immediate mental impression of an object perceived by sensation and the intellectual understanding of that object's nature abstracted from any individuating characteristics.

${ }^{12}$ See $S T:$ I.84.6, 8.

${ }^{13}$ See $Q D A$ : II; $S T$ : I.101.2.

${ }^{14}$ For the standard Latin edition of Pomponazzi's treatise, see Petrus Pomponatus, Tractatus de immortalitate animae [DIA], Gianfranco Morra, ed. (Bologna: Nanni and Fiammeghi, 1954). All quotations will be taken from the English translation, "On the Immortality of the Soul,” W.H. Hay II, trans., in Ernst Cassirer, et al., eds., Renaissance Philosophy of Man (Chicago: University of Chicago Press, 1948), pp. 280-381.

${ }^{15}$ DIA: Preface; Cassirer, p. 281.

${ }^{16}$ See DIA: Preface; Cassirer, p. 281.

${ }^{17}$ Pomponazzi first shows that Averroes's account also fails to meet the two criteria (see DIA: III-IV).

${ }^{18}$ An intellective soul's "aspiring to eternal things" apparently refers to its ability to know universal concepts (see ST: I.86.2.ad 4) and to be aware of things that exist outside of purely material conditions, such as angelic substances and God. Though, unlike its knowledge of universals, an intellective soul cannot have complete knowledge of things, such as God and angels, which do not exist in sensible material substances in some fashion (see ST: I.88). 
${ }^{19}$ DIA: VIII; Cassirer, p. 303. It should be noted that Pomponazzi does not deny that an intellective soul is in any way immortal; he admits that a human being "is to be placed as a mean between mortal and immortal things" (DIA: I; Cassirer, p. 282).

${ }^{20}$ DIA: VIII; Cassirer, p. 304.

${ }^{21}$ DIA: VIII; Cassirer, p. 304.

${ }^{22}$ DA: I.1.403a8ff. Translated by W.S. Hett (Cambridge: Harvard University Press, 1936).

${ }^{23}$ DA: III.7.431a17.

${ }^{24}$ DIA: VIII; Cassirer, p. 305.

${ }^{25}$ DA: II.1.412a19ff. See ST: I.75.1, 76.1 for Aquinas's adoption of this definition.

${ }^{26}$ See DA: III.5.430a22ff.

${ }^{27}$ Historical note: The thesis of DIA, that an intellective soul is mortal simpliciter and immortal secundum quid, was condemned, without Pomponazzi being specifically named, by the Lateran V Council under Pope Leo X in the bull Apostolici Regiminis on December 19, 1513. The Holy Inquisition condemned DIA and ordered copies of it publicly burned in Venice on June 13, 1518. Pope Leo X also ordered Pomponazzi to recant his position after commissioning several theologians to refute it. Among Pomponazzi's chief adversaries were Alessandro Achillini, Antonio Francanciano, and Agostino Nifo, who was one of the theologians ordered by Leo X to refute Pomponazzi's position. For further information on the historical background of Pomponazzi's treatment of the intellective soul and reactions to it, see Martin Pine, Pietro Pomponazzi: Radical Philosopher of the Renaissance (Padua: Editrice Atenore, 1986), chs. 1-2; George Vass, 
S.J., "The Immortality of the Soul and Life Everlasting" The Heythrop Journal 6 (1965): pp. 270-88, esp. pp. $272-8$.

${ }^{28}$ This response is also offered by John L. Treloar, S.J. in his "Pomponazzi's Critique of Aquinas's Arguments for the Immortality of the Soul" The Thomist 54/3 (1990): pp. 465-

6.

${ }^{29}$ See DA: II.3.414b29ff.

${ }^{30} S T$ : I.77.4. All translations of Aquinas's works are my own and are made from the critical Leonine edition: S. Thomae Aquinatis Doctoris Angelici Opera Omnia (Rome: Commissio Leonina, 1882- ).

${ }^{31}$ Aquinas, Compendium theologiae [CT]: 151.

${ }^{32}$ SG: IV.79. See my "The Metaphysics of Resurrection: Issues of Identity in Thomas Aquinas" American Catholic Philosophical Quarterly 74, Supp. (2000): pp. 215-30.

${ }^{33}$ DA: III.5.430a18.

${ }^{34}$ For discussion of the difficulty in interpreting this passage, see the essays by Franz Brentano, L.A. Kosman, and Charles H. Kahn in Martha Nussbaum and Amélie Oksenberg Rorty, Essays on Aristotle's De Anima (Oxford: Clarendon Press, 1992).

${ }^{35}$ See Aquinas, De unitate intellectus contra Averroistas; ST: I.79.1-5; Mark Ambrose, “Aristotle's Immortal Intellect” American Catholic Philosophical Quarterly 75, Supp. (2001): pp. 96-106.

${ }^{36}$ See DA: III.7.431a17; ST: I.84.6-8, 85.1.

${ }^{37}$ DIA: VIII; Cassirer, p. 306.

${ }^{38}$ For further discussion of how an aptitude for rationality—-termed an "active potentiality" by Aquinas — suffices for something to qualify as a human person, see my 
“Aquinas's Account of Human Embryogenesis and Recent Interpretations" Journal of Medicine and Philosophy 30/4 (2005): pp. 379-94.

${ }^{39} S T:$ I.89.1.

${ }^{40}$ The intelligible forms are provided to a separated intellective soul directly by God; see ST: I.89.1.ad 3.

${ }^{41}$ Dominick A. Iorio also notes Aquinas's response to this issue in his "The Problem of the Soul and the Unity of Man in Pietro Pomponazzi” New Scholasticism 37 (1963): pp. $304-6$.

${ }^{42}$ See ST: I.89.5.

${ }^{43} S T:$ I.89.6.

${ }^{44}$ RAM stands for "random access memory" and ROM stands for "read-only memory."

${ }^{45}$ Since being the form of a body is an essential property of an intellective soul, it can never cease having this property. Therefore, even after separation, an intellective soul must continue to be the form of a body in some way even though it is not conjoined to any body.

${ }^{46}$ Commentators on Aristotle from classical through contemporary times draw a distinction between two types of actuality: "first actuality," used explicitly by Aristotle to describe a soul's essential nature as the form of a body, and "second actuality," a term not used by Aristotle but implied by his distinguishing a first actuality. A first actuality can be understood as a "potential actualization." In other words, an actual power or property that is not, at present, being utilized. For example, if I am asleep, I am not utilizing my actual power of exercising knowledge, yet I still have this power as an actuality. I do not merely have the potential for knowledge, I have knowledge and have it 
even when I am asleep. If I am awake and thinking about a mathematical problem, then I have actualized my power for exercising knowledge, which would be a second actuality. This example can be found in $D A$ : II.1.412a22ff.

${ }^{47}$ See Eberl, op. cit. note 38.

${ }^{48}$ Aristotle discusses this in terms of movement. He states that a soul can move in the sense that it can move a body and the body it is in can move. There is no indication, however, that a soul can be moved by a body or anything else. See DA: I.3.406a2ff.

${ }^{49}$ See Eberl, op. cit. note 32.

${ }^{50}$ See the above discussion of ST: I.89.1.

${ }^{51}$ This is not to say that resurrection is a natural occurrence. Aquinas admits that a material body cannot resurrect itself; it must be resurrected by divine power (see $C T$ : 154). The necessity of resurrection, though, in accordance with the way in which God designed human nature, makes it incumbent upon God to resurrect the material bodies of separated intellective souls.

${ }^{52}$ I am most grateful to Eleonore Stump, Michael Burke, Michael White, Tom Blackson, and Bernard Kobes for comments on previous drafts of this paper, as well as to audience members at a graduate student conference at Arizona State University in April 1998, the $17^{\text {th }}$ annual conference of the Society of Ancient Greek Philosophy at SUNYBinghamton, the $40^{\text {th }}$ International Congress on Medieval Studies at Western Michigan University, and a Philosophy department colloquium at Providence College in November 2002. 